\title{
Quantification of cancer risk in glomerulonephritis
}

\author{
James Goya Heaf ${ }^{1 *}$ (D), Alastair Hansen ${ }^{2}$ and Gunnar Hellmund Laier $^{3}$
}

\begin{abstract}
Background: The association of increased cancer risk with glomerulonephritis (GN) is well known, but controversy exists concerning which types of GN are involved, and the size of the association. A national registry survey was performed to assess the size of this association, and the temporal relationship of cancer diagnosis to GN diagnosis.

Methods: All patients with biopsy-proven GN between 1985 and 2015 in Denmark were extracted from The Danish Renal Biopsy Registry and the National Pathology Data Bank. Incident cancer diagnoses between 10 years previous and 10 years subsequent to the GN diagnosis were extracted from the Danish Cancer Registry. Residence, birth and death data were obtained from the National Patient Register. Expected cancer incidence, classified according to cohort, age and sex were extracted from the Nordcan database.
\end{abstract}

Results: Nine hundred eleven cancers were diagnosed in 5594 patients. Thirty five percent were prevalent at renal biopsy. Prevalence at biopsy was 5.5\% (expected 3.1\%), but incidence was not increased $<1$ year before biopsy. Increased cancer rates were seen for GN forms: minimal change, endocapillary, focal segmental glomerulosclerosis, mesangioproliferative, membranous, focal segmental, membranoproliferative, proliferative, ANCA-associated vasculitis, lupus nephritis and unclassified. Increased cancer rates were seen for lung, prostate, renal, non-Hodgkin lymphoma, myeloma, leukaemia and skin. The increased incidence was mainly limited to -1 to 1 year after biopsy, but skin cancer showed an increased risk over time. Some diagnoses showed an increase 5-10 years after biopsy. Incidence was raised for patients with uraemia and nephrosis, but less for proteinuria or haematuria. Cancers in patients $<45$ years were rare. The risk of developing cancer 0-3 years after biopsy for patients 45-64 years varied from 7.3\% (minimal change) to 15.8\% (unclassified GN); > 64 years from 11.8 (endocapillary GN) to 20.3\% (unclassified). The diagnosis with the highest risk was membranoproliferative GN (8.6 \& 19.6\%).

Conclusions: Cancer rates are increased for many cancer and most GN diagnoses. Cancer screening for patients $<45$ years and for patients without nephrosis or uraemia may not be necessary. The findings suggest that screening programs for specific GN diagnoses can be extended to other GN forms.

Keywords: Cancer, Glomerulonephritis, Epidemiology, Nephrotic syndrome, Uraemia, Proteinuria, Haematuria

\section{Background}

The association of cancer with glomerulonephritis (GN) is well known, being described as early as 1966 [1]. Detailed reviews of the subject have been published [2-6]. Most forms of glomerulonephritis have been implicated: minimal change disease (MCD), membranous nephropathy (MN), focal segmental glomerulosclerosis (FSGS), mesangioproliferative GN (MesPGN), membranoproliferative GN (also known as mesangiocapillary GN) (MPGN), anti-

\footnotetext{
*Correspondence: heaf@dadlnet.dk

${ }^{1}$ Department of Medicine, Zealand University Hospital, Roskilde, Denmark

Full list of author information is available at the end of the article
}

GBM disease (anti-GBMGN), and ANCA-related vasculitis (ANCAV). Similarly, a large number of cancer forms have been implicated, including lung, colorectal, stomach, renal, bladder, prostate, gynaecologic, breast, thymoma, Hodgkin's lymphoma, non-Hodgkin's lymphoma, and leukaemia. However, most of these associations are based on small series, with a limited number of cancer cases, which do not permit statistical analysis. The relationship of $\mathrm{MN}$ to cancer, primarily solid tumours is the best documented, with a number of large series. A metaanalysis [7] showed a prevalence of $10 \%$, primarily lung, prostate, haematological and colorectal. 
Few population-based studies are available. The association of proteinuria with increased later cancer risk is well documented [8-10]. In a Norwegian national study of 161 patients with MN between 1988 and 2003 [11], the cancer incidence after biopsy was 2.4\%/year, 2.25 times the expected rate. Follow-up for 15 years did not seem to show a declining incidence. The largest population-based study was a Danish national study of all GN forms for the years 1985-96 [12]. This revealed 102 cancers in 1958 patients during a follow-up period of average 4.7 years, 1.93 times the expected value. Increased rates were seen for MCD, endocapillary GN (EndGN), MN, MesPGN, and unclassified GN. Cancers with increased rates were lung, skin, lymphatic and haematological, non-Hodgkin lymphoma, Hodgkin's disease and leukaemia. Haematological malignancy in particular was 7-17 times more common than expected.

This database has now continued prospectively for 30 years, and permits a detailed study of cancer incidence, with accurate measurement of risk. We decided to repeat the analysis, with a follow-up period of 10 years. In addition, cancers diagnosed up to 10 years previous to biopsy were included, allowing prevalence rates to be assessed.

\section{Methods}

All patients with biopsy-proven GN resident in Denmark between the years 1985-2014 were included. The great majority of patients were Caucasian.

The study was an observational study in epidemiology and followed the STROBE guidelines for reporting observational studies [13].

\section{Renal biopsies}

The renal biopsy information was derived from two registries:

1) Danish Renal Biopsy Registry (DANYBIR). This registry recorded all biopsies performed in Denmark between 1985 and 1999 [14]. The reproducibility of the glomerular diagnosis has been investigated and found acceptable with a kappa value of 0.61 [15].

2) Since 2000 renal biopsy results have been registered by the National Pathology Data Bank (Patobank).

The following SNOMED diagnoses were included (SNOMED codes in parentheses): MCD, (M00100, combined with proteinuria or nephrosis: S65080, S67020, or S67550), endocapillary GN (EndGN, M46870), FSGS (M53341), MesPGN (M46862), MN (M68130), MPGN (M46842), proliferative GN (ProlGN, M46810), focal segmental proliferative GN (FSPGN, M46811), Focal GN (M46861), necrotizing and crescentic GN (also known as extracapillary GN) (NCGN, M46880), unclassified GN
(M40000), anti-GBMGN (S67400), ANCAV (S76950), lupus nephritis (LN) (S38720). IgA GN was classified according to the light microscopy diagnosis, mainly MesPGN. Most cases of EndGN will have been infection-related GN. For each patient, only one biopsy was included, being the first biopsy with a GN diagnosis. Patients less than 15 years old were excluded. For biopsies with multiple GN diagnoses, the first mentioned diagnosis was chosen, with the following exceptions: anti-GBMGN and ANCAV were given first priority; MCD and unclassified GN were ignored in the presence of a more specific diagnosis. The presence in the biopsy of fibrosis (M49000-M49005) was noted.

Associated clinical diagnoses were registered (vide infra): Uraemia (SNOMED S65050, S65150, S65110 or ICD10 N03.x, N18.x), proteinuria (S65080 or N06.x), haematuria $(65,070$ or N02.x) and nephrotic syndrome (S67020, S67500, S67550 or N04.x).

\section{Cancer diagnoses}

Using the patient national identity number, these patients were linked with all registered cancer diagnoses in the Danish Cancer Registry, which has been in existence since 1943. ICD-8 diagnoses were converted to the relevant ICD - 10 diagnoses. The following diagnosis groups were used: colon \& rectum (C18.x -C21.x), lung (C26.xC34.x), melanoma (C43.x), skin (not melanoma) (C44.x), breast (C50.0) gynaecologic (C54.x-C57.x), prostate (C61.x), renal (C64.x-c66.x), bladder (C67.x), Hodgkin lymphoma (C81.x), non-Hodgkin lymphoma (C82.xc88.x), myeloma (C90.x), leukaemia (C91.x-C95.x), unclassified (all other Cxx.x diagnoses).

All diagnosis groups were incident at first diagnosis day, thereafter they were regarded as prevalent. "Any" cancer diagnosis was incident on the first day of the first cancer diagnosis, and was thereafter prevalent. Thus "Any cancer" prevalence will usually be less than the sum of individual cancer prevalences, since multiple cancers were not included.

\section{Cancer epidemiology}

The Danish Cancer Registry exports all cancer data to the Nordic Cancer database (Nordcan) [16], which publishes yearly incident and prevalent data, stratified by diagnosis, 10-year age groups and sex. Data was extracted for three biopsy cohorts (1985-94, 1995-2004, 2005-2014), based on the results for 1990, 2000, and 2010 respectively.

\section{Patient data}

Patient sex and birthday were calculated from the national identity number. Patients entered the study 10 years before the biopsy and were lost to follow-up (LTF) 10 years after, unless censored for death or 
emigration. Dates of immigration, emigration and death were extracted from the National Patient Registry (LPR). Clinical renal diagnoses (ICD-10 N03.x, N18.x, N02.x, N04.x, N06.x) were also extracted (vide supra).

\section{Calculations}

Observation periods were: $10-5$ years, $5-3$ years, $3-1$ years and $1-0$ years before biopsy; $0-1,1-3,3-5,5-10$ years after biopsy. Analyses of prevalent rates at biopsy used the observation period $10-0$ years before biopsy; overall cancer incidence -10 to +10 years. These observation periods were derived from the NORDCAN database.

The incidence of cancer increases with age. In order to measure this, for each year after biopsy, $10 \%$ of patients were assumed to move into the next 10-year age cohort.

For each observation period, the real observation period was often shorter than the defined, due to immigration, emigration or death. While this effect was minimal for periods before biopsy, it was substantial for periods after biopsy, particularly 3-10 years after biopsy, and was greater in the older age groups. The real average observation period for the relevant renal diagnosis and age group (15-44 years; 45-64 years; > 64 years) was used in calculations.

For incidence rates before biopsy, the rate of (by definition) survivable cancers was used. Thus, the incidence rate was measured by changes in prevalence rate.
Number of observed incident cancer episodes per time interval, and the expected incidence (\%/year) were thus available. The observed incidence (\%/yr) was defined as the number of observed cases divided by the average observation period. The expected number of cases in the time interval was defined as expected incidence multiplied by the average time period.

\section{Statistics}

Statistical analysis was based on observed and expected cases. Confidence intervals and $p$-values for indirect standardized incidence ratios were calculated using the Poisson model for number of incident cancer cases given time at risk and population level incidence rates adjusted for age and calendar year.

\section{Results}

The follow-up period was $6.4 \pm 3.7$ years; for patients followed for more than 5 years $7.5 \pm 0.9$ years. Nine hundred eleven cancers were diagnosed in 5594 patients.

\section{Glomerulonephritis and prevalent cancer}

Three hundred thirty (36\%) cancers diagnoses were prevalent at renal biopsy. Patient details and prevalence at biopsy are shown in Table 1 . Prevalence at biopsy was $5.5 \%$ (expected $3.1 \%$ ), but prevalence was only slightly increased $<1$ year before biopsy, where it rose rapidly.

Table 1 Patient age, sex, and cancer prevalence at diagnosis (observed vs. expected)

\begin{tabular}{|c|c|c|c|c|c|c|c|}
\hline & $\begin{array}{l}\text { No. } \\
\text { patients }\end{array}$ & $\begin{array}{l}\text { Age } \\
\text { (yrs) }\end{array}$ & $\begin{array}{l}\text { Female } \\
(\%)\end{array}$ & $\begin{array}{l}\text { Patients with } \\
\text { Cancer }\end{array}$ & $\begin{array}{l}\text { Prevalence } \\
(\%)\end{array}$ & $\begin{array}{l}\text { Expected } \\
\text { prevalence (\%) }\end{array}$ & $\begin{array}{l}\text { Risk } \\
\text { Ratio }\end{array}$ \\
\hline Minimal change & 428 & $43,3 \pm 19$ & 46 & 19 & 4,4 & 1.9 & $2.4(1.4-3.7)^{c}$ \\
\hline Endocapillary & 137 & $43,4 \pm 18$ & 53 & 7 & 5,1 & 1.7 & $3.0(1.2-6.2)^{\mathrm{a}}$ \\
\hline $\begin{array}{l}\text { Focal segmental } \\
\text { glomerulosclerosis }\end{array}$ & 408 & $49,0 \pm 17$ & 34 & 27 & 6,6 & 2.7 & $2.4(1.6-3.5)^{c}$ \\
\hline Mesangioproliferative & 1185 & $42,2 \pm 17$ & 36 & 36 & 3,0 & 1.7 & $1,8(1.2-2.5)^{\mathrm{b}}$ \\
\hline Membranous & 741 & $52,3 \pm 17$ & 41 & 37 & 5,0 & 3.2 & $1.5(1.1-2.1)^{\mathrm{a}}$ \\
\hline Membranoproliferative & 298 & $49,2 \pm 17$ & 50 & 22 & 7,4 & 2.4 & $3.1(1.9-4.7)^{c}$ \\
\hline Proliferative & 113 & $43,4 \pm 19$ & 46 & 7 & 6,2 & 2.1 & $2.9(1.2-6.0)^{\mathrm{a}}$ \\
\hline $\begin{array}{l}\text { Focal segmental } \\
\text { proliferative }\end{array}$ & 507 & $47,3 \pm 19$ & 36 & 15 & 3,0 & 2.3 & $1,3(0.7-2.1)$ \\
\hline Focal & 146 & $56,1 \pm 17$ & 41 & 6 & 4,1 & 3.1 & $1.3(0.5-1.8)$ \\
\hline Crescentic & 610 & $58,4 \pm 16$ & 39 & 27 & 4,4 & 3.9 & $1.1(0.7-1.6)$ \\
\hline Unclassified & 552 & $55,4 \pm 18$ & 41 & 82 & 14,9 & 3.0 & $4.9(3.9-6.1)^{c}$ \\
\hline Anti-GBMGN & 92 & $55,5 \pm 22$ & 53 & 1 & 1,1 & 4.4 & $0.2(0-1.4)$ \\
\hline ANCA associated vasculitis & 278 & $59,1 \pm 16$ & 38 & 21 & 7,6 & 4.2 & $1,8(1.1-2.5)^{\mathrm{a}}$ \\
\hline $\begin{array}{l}\text { Lupus nephritis } \\
\text { unspecified }\end{array}$ & 99 & $38,1 \pm 17$ & 77 & 1 & 1,0 & 1.5 & $0,7(0-3.8)$ \\
\hline Lupus nephritis all & 422 & $36.4 \pm 15$ & 77 & 7 & 1.7 & 0.7 & $1.2(0.5-2.5)$ \\
\hline Any & 5594 & $49.4 \pm 18$ & 41 & 330 & 5.5 & 3.1 & $1,8(1.4-2.1)^{c}$ \\
\hline
\end{tabular}

Significant risk ratios in bold type

${ }^{a}:<0.05 ;^{b}:<0.01{ }^{c}{ }^{c}<0.001$ 
Prevalence was raised for most GN diagnoses, with the exception of FSPGN, Focal GN, NCGN, anti-GBMGN and LN. Diagnoses with the highest prevalence were: unclassified, ANCAV, MPGN, FSGS and ProlGN.

\section{Glomerulonephritis and cancer incidence}

Incidence rates for GN are shown in Table 2 and Fig. 1. Incidence was slightly increased up to 1 year before biopsy, but then rose rapidly for the period of -1 to 1 year, to a maximum of $2.5 \% / \mathrm{yr}$. The increase was related to age (Fig. 2): < 45 years $0.5 \% /$ yr., $45-64$ years $2.7 \% / y r$ and $>64$ $5.6 \% / y r$. This pattern was present for MCD, EndGN, FSGS, MesPGN, MN, MPGN, ProlGN, LN, ANCAV and unclassified, but no increase was seen for focal GN, NCGN, or anti-GBMGN. About $40 \%$ of this increase was prevalent at biopsy, with the exception of $\mathrm{MN}$, where only $20 \%$ was present. Incidence then fell, and was no longer significant at 3-5 years (Fig. 3, pattern a). This pattern was seen for the diagnoses MCD, EndGN, MPGN and unclassified. For some GN diagnoses (MesPGN, ProlGN, FSGS, MN), after an initial fall, an increased incidence was seen after 5 years (Fig. 3, pattern b). One GN diagnosis (FSPGN) showed a gradually increasing incidence (pattern C). The presence of fibrosis in the biopsy (14\%) did not affect the cancer incidence.

Ninety nine patients had unspecified lupus as primary diagnosis. A further 323 patients had lupus as secondary diagnosis. Their primary diagnoses were MesPGN (38\%), MN (15\%), MPGN (13\%), ProlGN (9\%) FS ProlGN (8\%), End (7\%), NCGN (5\%) and unclassified (5\%). Cancer risk was increased for all lupus patients combined, primarily after renal biopsy.

\section{Relationship of cancer type to incidence}

Incidence rates for cancer are shown in Table 3. Pattern A was seen for the following cancer diagnoses (maximum incidence in \%/yr. in brackets): lung (0.3), renal (0.3), nonHodgkin lymphoma (0.2), myeloma (0.4), leukaemia $(0.17)$, prostate $(0.7)$, unclassified $(0.5)$. Renal and unclassified cancers showed an increased incidence after 5 years. Unclassified cancers were mostly non-specific, but included 10 cases of gastric cancer and 10 cases of pancreatic cancer. Non-melanoma skin cancers followed a different pattern, with an increased incidence throughout the period of observation, rising from $0.1 \%$ /year 10 to 5 years prior to biopsy to 0.7 five to 10 years after (Fig. 3, pattern c). The late (5-10 years post-biopsy) overall increase in cancer incidence was almost entirely related to this increase in skin cancers. No increase in incidence was seen for melanoma, breast, gynaecologic, bladder, or Hodgkin lymphoma. The incidence of colorectal cancer was reduced. Other cancers associated with GN in the literature are shown in Table 4. These cancers were rare, not permitting statistical analysis.

\section{Relationship of cancer incidence to Nephrological diagnosis}

Clinical data was available was available for 4339 (78\%) of biopsies: uraemia (62\%), nephrotic syndrome $(30 \%)$, proteinuria $(15 \%)$ and haematuria $(6 \%)$. Most of the increased risk was related to the diagnoses uraemia and nephrotic syndrome. Patients with haematuria had an overall increase risk (RR $1.5(1.0-2.2), p<0.05)$, but this was restricted to a late increase (5-10 years RR $3.2(1.7-5.5)$, $p<0.001)$. Similarly, the overall relationship between

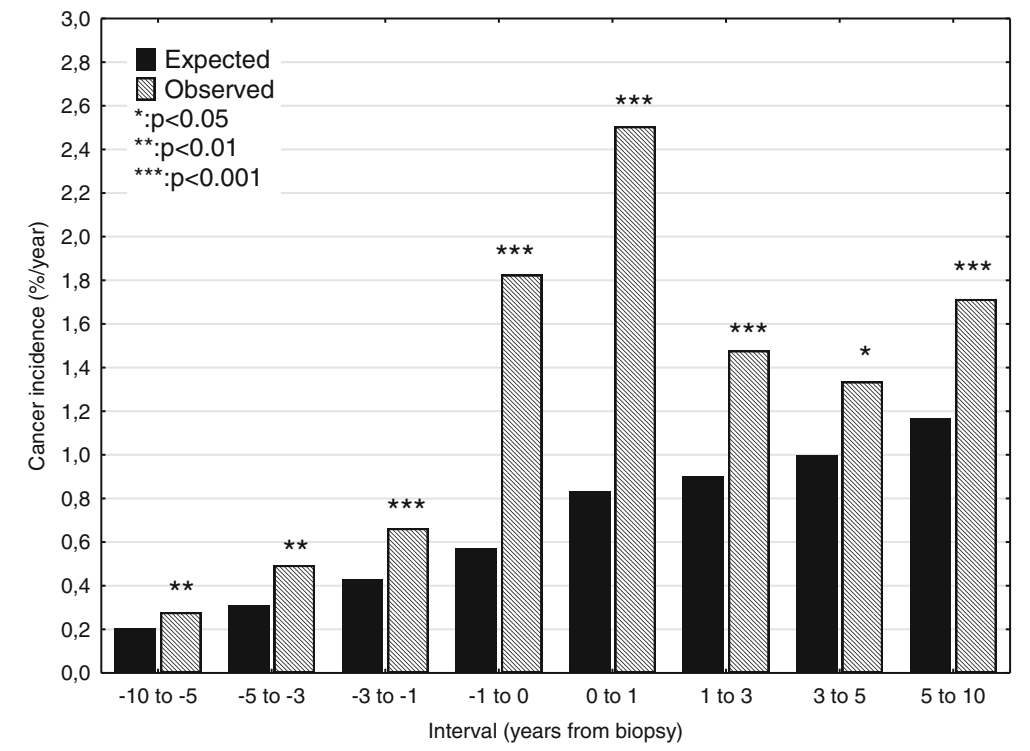

Fig. 1 Observed and expected any cancer incidences for all biopsied 
Table 2 The association of renal diagnosis to observed and expected cancer incidence (\%/year) grouped according to time interval relative to biopsy date

\begin{tabular}{|c|c|c|c|c|c|c|c|c|c|c|}
\hline Time interval (years) & & -10 to -5 & -5 to -3 & -3 to -1 & -1 to 0 & $0-1$ & $1-3$ & $3-5$ & $5-10$ & -10 to 10 \\
\hline \multirow{3}{*}{$\begin{array}{l}\text { Minimal } \\
\text { change }\end{array}$} & Observed & 0.19 & 0.24 & 0.82 & 1.40 & 2.44 & 1.39 & 0.64 & 0.72 & 0.73 \\
\hline & Expected & 0.15 & 0.23 & 0.31 & 0.41 & 0.59 & 0.64 & 0.71 & 0.84 & 0.45 \\
\hline & Risk ratio & $\begin{array}{l}1.2 \\
(0.3-3.2)\end{array}$ & $\begin{array}{l}1.0 \\
(0.1-3.8)\end{array}$ & $\begin{array}{l}2.6 \\
(1.1-5.4)^{\mathrm{a}}\end{array}$ & $\begin{array}{l}3.4 \\
(1.2-7.4)^{b}\end{array}$ & $\begin{array}{l}4.1 \\
(2.0-7.6)^{c}\end{array}$ & $\begin{array}{l}2.2 \\
(1.0-4.0)^{\mathrm{a}}\end{array}$ & $\begin{array}{l}0.9 \\
(0.2-2.3)\end{array}$ & $\begin{array}{l}0.9 \\
(0.4-1.6)\end{array}$ & $\begin{array}{l}1.6 \\
(1.2-2.1)^{c}\end{array}$ \\
\hline \multirow[t]{3}{*}{ Endocapillary } & Observed & 0.15 & 0.36 & 1.09 & 1.46 & 3.32 & 0.50 & 1.51 & 0.29 & 0.72 \\
\hline & Expected & 0.14 & 0.21 & 0.29 & 0.39 & 0.58 & 0.63 & 0.71 & 0.84 & 0.42 \\
\hline & Risk ratio & $\begin{array}{l}1.1 \\
(0-6.1)\end{array}$ & $\begin{array}{l}1.8 \\
(0-9.9)\end{array}$ & $\begin{array}{l}3.8 \\
(0.8-11.2)^{a}\end{array}$ & $\begin{array}{l}3.7 \\
(0.4-13.4)\end{array}$ & $\begin{array}{l}5.8 \\
(1.6-14.7)^{b}\end{array}$ & $\begin{array}{l}0.8 \\
(0-4.4)\end{array}$ & $\begin{array}{l}2.1 \\
(0.3-7.7)\end{array}$ & $\begin{array}{l}0.3 \\
(0-1.9)\end{array}$ & $\begin{array}{l}1.7 \\
(1.0-2.9)^{\mathrm{a}}\end{array}$ \\
\hline \multirow{3}{*}{$\begin{array}{l}\text { Focal segmental } \\
\text { glomerulosclerosis }\end{array}$} & Observed & 0.35 & 0.74 & 0.86 & 1.72 & 2.08 & 1.05 & 0.92 & 2.10 & 0.96 \\
\hline & Expected & 0.20 & 0.32 & 0.44 & 0.57 & 0.81 & 0.89 & 1.00 & 1.19 & 0.57 \\
\hline & Risk ratio & $\begin{array}{l}1.8 \\
(0.7-3.6)\end{array}$ & $\begin{array}{l}2.3 \\
(0.9-5.1)^{\mathrm{a}}\end{array}$ & $\begin{array}{l}1.9 \\
(0.8-4.0)\end{array}$ & $\begin{array}{l}3.0 \\
(1.2-6.2)^{\mathrm{a}}\end{array}$ & $\begin{array}{l}2.5 \\
(1.1-5.0)^{\mathrm{a}}\end{array}$ & $\begin{array}{l}1.2 \\
(0.5-2.4)\end{array}$ & $\begin{array}{l}0.9 \\
(0.3-2.4)\end{array}$ & $\begin{array}{l}1.8 \\
(0.9-3.0)^{p}=0.06\end{array}$ & $\begin{array}{l}1.7 \\
(1.3-2.2)^{c}\end{array}$ \\
\hline \multirow{3}{*}{$\begin{array}{l}\text { Mesangio- } \\
\text { proliferative }\end{array}$} & Observed & 0.17 & 0.38 & 0.34 & 0.76 & 1.05 & 0.83 & 0.97 & 1.14 & 0.58 \\
\hline & Expected & 0.12 & 0.19 & 0.26 & 0.36 & 0.50 & 0.56 & 0.63 & 0.77 & 0.38 \\
\hline & Risk ratio & $\begin{array}{l}1.4 \\
(0.7-2.6)\end{array}$ & $\begin{array}{l}2.0 \\
(0.9-3.9)^{\mathrm{a}}\end{array}$ & $\begin{array}{l}1.3 \\
(0.6-2.5)\end{array}$ & $\begin{array}{l}2.1 \\
(1.0-4.1)^{a}\end{array}$ & $\begin{array}{l}2.1 \\
(1.0-3.8)^{a}\end{array}$ & $\begin{array}{l}1.5 \\
(0.8-2.5)\end{array}$ & $\begin{array}{l}1.5 \\
(0.9-2.5)\end{array}$ & $\begin{array}{l}1.5 \\
(1.0-2.1)^{\mathrm{a}}\end{array}$ & $\begin{array}{l}1.5 \\
(1.2-1.8)^{c}\end{array}$ \\
\hline \multirow[t]{3}{*}{ Membranous } & Observed & 0.30 & 0.55 & 0.74 & 0.94 & 3.90 & 1.77 & 0.93 & 2.39 & 1.10 \\
\hline & Expected & 0.22 & 0.33 & 0.47 & 0.62 & 0.91 & 0.99 & 1.10 & 1.30 & 0,65 \\
\hline & Risk ratio & $\begin{array}{l}1.4 \\
(0.7-2.5)\end{array}$ & $\begin{array}{l}1.6 \\
(0.7-3.2)\end{array}$ & $\begin{array}{l}1.6 \\
(0.8-2.9)\end{array}$ & $\begin{array}{l}1.5 \\
(0.6-3.1)\end{array}$ & $\begin{array}{l}4.3 \\
(2.8-6.3)^{c}\end{array}$ & $\begin{array}{l}1.8 \\
(1.1-2.8)^{\mathrm{a}}\end{array}$ & $\begin{array}{l}0.8 \\
(0.4-1.6)\end{array}$ & $\begin{array}{l}1.8 \\
(1.3-2.6)^{c}\end{array}$ & $\begin{array}{l}1.7 \\
(1.4-2.0)^{c}\end{array}$ \\
\hline \multirow{3}{*}{$\begin{array}{l}\text { Membrano- } \\
\text { proliferative }\end{array}$} & Observed & 0.48 & 0.34 & 0.68 & 3.04 & 3.81 & 2.24 & 1.45 & 1.05 & 1.18 \\
\hline & Expected & 0.20 & 0.30 & 0.42 & 0.54 & 0.78 & 0.85 & 0.94 & 1.10 & 0.55 \\
\hline & Risk ratio & $\begin{array}{l}2.4 \\
(1.0-4.9)^{a}\end{array}$ & $\begin{array}{l}1.1 \\
(0.1-4.0)\end{array}$ & $\begin{array}{l}1.6 \\
(0.4-4.1)\end{array}$ & $\begin{array}{l}5.6 \\
(2.6-10.6)^{c}\end{array}$ & $\begin{array}{l}4.9 \\
(2.3-9.0)^{c}\end{array}$ & $\begin{array}{l}2.6 \\
(1.2-5.0)^{b}\end{array}$ & $\begin{array}{l}1.5 \\
(0.4-4.0)\end{array}$ & $\begin{array}{l}1.0 \\
0.4-2.0)\end{array}$ & $\begin{array}{l}2.2 \\
(1.6-2.8)^{c}\end{array}$ \\
\hline \multirow[t]{3}{*}{ Proliferative } & Observed & 0.53 & 0 & 0.88 & 1.78 & 1.92 & 0 & 0 & 2.95 & 0.87 \\
\hline & Expected & 0.14 & 0.22 & 0.31 & 0.41 & 0.60 & 0.66 & 0.74 & 0.88 & 0.43 \\
\hline & Risk ratio & $\begin{array}{l}3.7 \\
(0.8-10.8)^{a}\end{array}$ & $\begin{array}{l}0 \\
(0-7.6)\end{array}$ & $\begin{array}{l}2.9 \\
(0.3-10.4)\end{array}$ & $\begin{array}{l}4.3 \\
(0.5-15.5)\end{array}$ & $\begin{array}{l}3.2 \\
(0.4-11.5)\end{array}$ & $\begin{array}{l}0 \\
(0-3.2)\end{array}$ & $\begin{array}{l}0 \\
(0-3.5)\end{array}$ & $\begin{array}{l}3.4 \\
(1.1-7.8)^{c}\end{array}$ & $\begin{array}{l}2.0 \\
(1.1-3.4)^{\mathrm{a}}\end{array}$ \\
\hline \multirow{3}{*}{$\begin{array}{l}\text { Focal segmental } \\
\text { proliferative }\end{array}$} & Observed & 0.16 & 0.20 & 0.49 & 0.79 & 1.14 & 1.29 & 1.50 & 1.76 & 0.74 \\
\hline & Expected & 0.17 & 0.26 & 0.36 & 0.49 & 0.71 & 0.78 & 0.87 & 1.02 & 0.52 \\
\hline & Risk ratio & $\begin{array}{l}0.9 \\
(0.3-2.4)\end{array}$ & $\begin{array}{l}0.8 \\
(0.1-2.8)\end{array}$ & $\begin{array}{l}1.4 \\
(0.5-3.2)\end{array}$ & $\begin{array}{l}1.6 \\
(0.4-4.2)\end{array}$ & $\begin{array}{l}1.6 \\
(0.5-3.7)\end{array}$ & $\begin{array}{l}1.7 \\
(0.8-3.0)\end{array}$ & $\begin{array}{l}1.7 \\
(0.8-3.2)\end{array}$ & $\begin{array}{l}1.7 \\
(1.1-2.6)^{\mathrm{a}}\end{array}$ & $\begin{array}{l}1.4 \\
(1.1-1.8)^{b}\end{array}$ \\
\hline \multirow[t]{3}{*}{ Focal } & Observed & 0 & 1.03 & 0.35 & 1.37 & 1.67 & 0.66 & 2.48 & 0.95 & 0.70 \\
\hline & Expected & 0.29 & 0.44 & 0.61 & 0.78 & 1.14 & 1.23 & 1.34 & 1.55 & 0.75 \\
\hline & Risk ratio & $\begin{array}{l}0 \\
(0-1.8)\end{array}$ & $\begin{array}{l}2.3 \\
(0.5-6.9)\end{array}$ & $\begin{array}{l}0.6 \\
(0-3.3)\end{array}$ & $\begin{array}{l}1.8 \\
(0.2-6.4)\end{array}$ & $\begin{array}{l}1.5 \\
(0.2-5.3)\end{array}$ & $\begin{array}{l}0.5 \\
(0-3.0)\end{array}$ & $\begin{array}{l}1.9 \\
(0.4-5.4)\end{array}$ & $\begin{array}{l}0.6 \\
(0.1-1.8)\end{array}$ & $\begin{array}{l}0.9 \\
(0.5-1.6)\end{array}$ \\
\hline \multirow[t]{3}{*}{ Crescentic } & Observed & 0.23 & 0.49 & 0.49 & 1.31 & 1.00 & 1.88 & 2.49 & 2.28 & 0.91 \\
\hline & Expected & 0.30 & 0.46 & 0.64 & 0.84 & 1.25 & 1.34 & 1.46 & 1.67 & 0.79 \\
\hline & Risk ratio & $\begin{array}{l}0.8 \\
(0.3-1.6)\end{array}$ & $\begin{array}{l}1.1 \\
(0.4-2.3)\end{array}$ & $\begin{array}{l}0.8 \\
(0.3-1.9)\end{array}$ & $\begin{array}{l}1.6 \\
(0.7-3.1)\end{array}$ & $\begin{array}{l}0.8 \\
(0.3-1.9)\end{array}$ & $\begin{array}{l}1.4 \\
(0.8-2.4)\end{array}$ & $\begin{array}{l}1.7 \\
(0.9-2.9)\end{array}$ & $\begin{array}{l}1.4 \\
(0.8-2.1)\end{array}$ & $\begin{array}{l}1.2 \\
(0.9-1.4)\end{array}$ \\
\hline \multirow[t]{3}{*}{ Unclassified } & Observed & 0.58 & 1.09 & 1.18 & 7.43 & 6.71 & 2.41 & 1.44 & 2.10 & 1.94 \\
\hline & Expected & 0.28 & 0.43 & 0.59 & 0.77 & 1.14 & 1.22 & 1.33 & 1.52 & 0.74 \\
\hline & Risk ratio & $\begin{array}{l}2.1 \\
(1.2-3.3)^{\mathrm{a}}\end{array}$ & $\begin{array}{l}2.5 \\
(1.3-4.4)^{b}\end{array}$ & $\begin{array}{l}2.0 \\
(1.1-3.4)^{\mathrm{a}}\end{array}$ & $\begin{array}{l}9.7 \\
(6.9-13.1)^{c}\end{array}$ & $\begin{array}{l}5,9 \\
(4.0-8.3)^{c}\end{array}$ & $\begin{array}{l}2,0 \\
(1.2-3.1)^{b}\end{array}$ & $\begin{array}{l}1.1 \\
(0.4-2.2)\end{array}$ & $\begin{array}{l}1.4 \\
(0.8-2.3)\end{array}$ & $\begin{array}{l}2.6 \\
(2.2-3.1)^{c}\end{array}$ \\
\hline \multirow[t]{3}{*}{ Anti-GBM GN } & Observed & 0.00 & 0.54 & 0.00 & 0.00 & 1.22 & 3.11 & 0.00 & 2.93 & 0.6 \\
\hline & Expected & 0.31 & 0.46 & 0.62 & 0.80 & 1.20 & 1.26 & 1.34 & 1.49 & 0.7 \\
\hline & Risk ratio & $\begin{array}{l}0 \\
(0-2.6)\end{array}$ & $\begin{array}{l}1.2 \\
(0-6.6)\end{array}$ & $\begin{array}{l}0 \\
(0-3.3)\end{array}$ & $\begin{array}{l}0 \\
(0-5.1)\end{array}$ & $\begin{array}{l}1.0 \\
(0-5.7)\end{array}$ & $\begin{array}{l}2.5 \\
(0.5-7.2)\end{array}$ & $\begin{array}{l}0 \\
(0-2.8)\end{array}$ & $\begin{array}{l}2.0 \\
(0.4-5.8)\end{array}$ & $\begin{array}{l}0.8 \\
(0.4-1.6)\end{array}$ \\
\hline \multirow{3}{*}{$\begin{array}{l}\text { ANCA-associated } \\
\text { vasculitis }\end{array}$} & Observed & 0.50 & 0.54 & 1.08 & 1.80 & 2.96 & 1.90 & 2.43 & 2.48 & 1.37 \\
\hline & Expected & 0.29 & 0.45 & 0.62 & 0.84 & 1.27 & 1.36 & 1.48 & 1.69 & 0.84 \\
\hline & Risk ratio & $\begin{array}{l}1.72 \\
(0.7-3.5)\end{array}$ & $\begin{array}{l}1.2 \\
(0.2-3.5)\end{array}$ & $\begin{array}{l}1.7 \\
(0.6-3.8)\end{array}$ & $\begin{array}{l}2.1 \\
(0.7-5.0)\end{array}$ & $\begin{array}{l}2.3 \\
(0.9-4.8)\end{array}$ & $\begin{array}{l}1.4 \\
(0.6-2.9)\end{array}$ & $\begin{array}{l}1.6 \\
(0.7-3.1)\end{array}$ & $\begin{array}{l}1.5 \\
(0.8-2.5)\end{array}$ & $\begin{array}{l}1.6 \\
(1.2-2.1)^{c}\end{array}$ \\
\hline
\end{tabular}


Table 2 The association of renal diagnosis to observed and expected cancer incidence (\%/year) grouped according to time interval relative to biopsy date (Continued)

\begin{tabular}{|c|c|c|c|c|c|c|c|c|c|c|}
\hline Time interval (years) & & -10 to -5 & -5 to -3 & -3 to -1 & -1 to 0 & $0-1$ & $1-3$ & $3-5$ & $5-10$ & -10 to 10 \\
\hline \multirow{3}{*}{$\begin{array}{l}\text { Lupus nephritis } \\
\text { unspecified }\end{array}$} & Observed & 0 & 0 & 0.51 & 0 & 1.14 & 1.71 & 2.40 & 0.75 & 0.60 \\
\hline & Expected & 0.10 & 0.15 & 0.21 & 0.28 & 0.40 & 0.44 & 0.49 & 0.59 & 0.31 \\
\hline & Risk ratio & $\begin{array}{l}0 \\
(0-7.9)\end{array}$ & $\begin{array}{l}0 \\
(0-12.7)\end{array}$ & $\begin{array}{l}2.4 \\
(0.1-13.6)\end{array}$ & $\begin{array}{l}0 \\
(0-13.3)\end{array}$ & $\begin{array}{l}2.9 \\
(0.1-15.9)\end{array}$ & $\begin{array}{l}3.9 \\
(0.5-14.0)\end{array}$ & $\begin{array}{l}4.9 \\
(0.6-17.6)\end{array}$ & $\begin{array}{l}1.3 \\
(0.3-3.7)\end{array}$ & $\begin{array}{l}1.9 \\
(0.9-3.7)\end{array}$ \\
\hline \multirow[t]{3}{*}{ Lupus nephritis all } & Observed & 0.10 & 0.24 & 0.24 & 0.24 & 0.78 & 0.83 & 0.56 & 0.89 & 0.42 \\
\hline & Expected & 0.09 & 0.14 & 0.19 & 0.25 & 0.34 & 0.38 & 0.43 & 0.52 & 0.26 \\
\hline & Risk ratio & $\begin{array}{l}1.1 \\
(0.1-3.9)\end{array}$ & $\begin{array}{l}1.7 \\
(0.2-6.3)\end{array}$ & $\begin{array}{l}1.2 \\
(0.1-4.4)\end{array}$ & $\begin{array}{l}0.9 \\
(0-5.3)\end{array}$ & $\begin{array}{l}2.3 \\
(0.5-6.8)\end{array}$ & $\begin{array}{l}2.2 \\
(0.7-5.2)\end{array}$ & $\begin{array}{l}1.3 \\
(0.2-4.7)\end{array}$ & $\begin{array}{l}1.7 \\
(0.9-3.0)\end{array}$ & $\begin{array}{l}1.6 \\
(1.1-2.3)^{a}\end{array}$ \\
\hline \multirow[t]{3}{*}{ Any } & Observed & 0.28 & 0.49 & 0.66 & 1.83 & 2.51 & 1.48 & 1.34 & 1.71 & 0.96 \\
\hline & Expected & 0.20 & 0.31 & 0.43 & 0.57 & 0.83 & 0.90 & 1.00 & 1.17 & 0.58 \\
\hline & Risk ratio & $\begin{array}{l}1.4 \\
(1.1-1.7)^{b}\end{array}$ & $\begin{array}{l}1.6 \\
(1.2-2.1)^{b}\end{array}$ & $\begin{array}{l}1.5 \\
(1.2-1.9)^{c}\end{array}$ & $\begin{array}{l}3.2 \\
(2.6-3.9)^{c}\end{array}$ & $\begin{array}{l}3.0 \\
(2.5-3.6)^{c}\end{array}$ & $\begin{array}{l}1.6 \\
(1.4-2.0)^{\mathrm{c}}\end{array}$ & $\begin{array}{l}1.3 \\
(1.1-1.7)^{\mathrm{a}}\end{array}$ & $\begin{array}{l}1.5 \\
(1.3-1.7)^{c}\end{array}$ & $\begin{array}{l}1.7 \\
(1.5-1.8)^{c}\end{array}$ \\
\hline
\end{tabular}

Significant risk ratios in bold type

$a_{:}<0.05 ;{ }^{b}:<0.01 ;{ }^{c}:<0.001$

proteinuria and cancer (RR 1.4 (1.1-1.8) was only apparent after 1 year post-biopsy.

\section{Relationship of specific Glomerulonephritis diagnoses with cancer diagnosis}

Cancer incidence was only slightly increased up to 1 year prior to biopsy. In order to evaluate the specific relationship between GN and cancer, the number of expected cases between -1 to +10 years after biopsy was subtracted from the observed number. The total number of excess cases (observed minus expected) was 378. Distributions of excess cancers by GN and cancer diagnoses are shown in Tables 5 and 6, along with common associations in the literature. Considerable differences between observed and previously described associations were seen. With the exception of skin cancer which showed a generally increased risk for most cancer types, the number of cases per diagnosis was too small for statistical analysis, and clear patterns were not observed.

Assuming that all cancers occurring from 0 to 3 years after biopsy are diagnosable by invasive means at biopsy, the expected risk of different cancer forms during this period, grouped according to GN diagnosis, are shown in Table 7 and the overall incidence in Fig. 4.

\section{Discussion}

The present study is the largest study of the relationship between GN and cancer, and permits a quantitative assessment of cancer risk for common forms of GN and cancer, and the temporal relationship between the two diseases. A further strength is that incidence was compared with the expected age- and sex-adjusted incidence in the general population. It confirms the increased cancer incidence seen in the previous study using this database [12] for MCD, EndGN, MN, MesPGN and unclassified GN. FSGS, ProlGN FSPGN, ANCAV and
$\mathrm{LN}$ ratio were added to the list but no increase was seen for focal GN, NCGN, or anti-GBMGN. These findings are in general accord with the literature [2-6]. IgA GN and Henoch-Schönlein purpura were not specifically studied in this paper, but most of these patients will have had MesPGN.

As in the previous study, cancers with increased rates were lung, skin, non-Hodgkin lymphoma, and leukaemia. However increased rates for colorectal cancer and Hodgkin's lymphoma could not be confirmed. Myeloma, renal, prostate and unclassified tumours were added to the list. These differences may simply due to chance given the large number of comparisons. Most of these findings have previously been described. However, the study does not support previously described relationships to e.g. Hodgkin's lymphoma [7, 17], colorectal [7] and gastric cancer [3]. Some of these findings may be due to a type 2 statistical error due to relative paucity of the tumours. For instance, the lack of any cases of thymoma preclude any contribution to its well-documented role in GN [18]. Perhaps the most surprising finding is that non-melanoma skin tumours were the most common cancer form for several GN diagnoses. Indeed, the finding is probably an underestimate, in that cancers were considered prevalent at first diagnosis; most skin cancers can be expected to be definitively cured shortly after diagnosis. This observation has received little previous attention.

About $40 \%$ of excess cancers were present at biopsy, except for MN, where the figure was $20 \%$. This is in accordance with the metaanalysis of MN by Leeaphorn et al. [7].

An epidemiological study can contribute little to a discussion of aetiology. Possible explanations include cancer causing GN, GN causing cancer due to the immunosuppressive effects of nephrosis and uraemia, immunosuppressive effects of GN therapy, or both being 


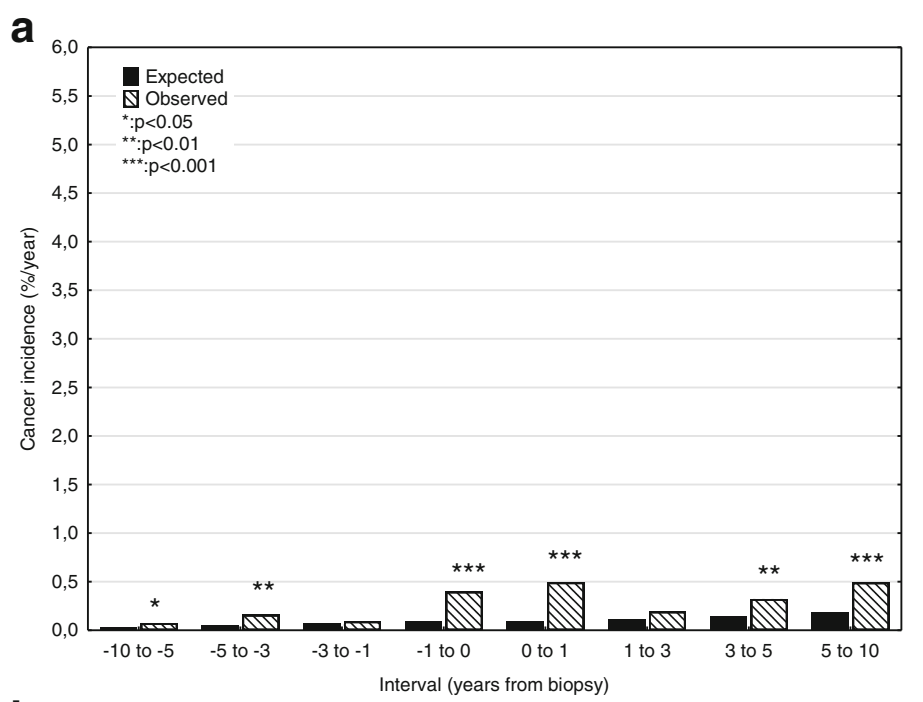

b

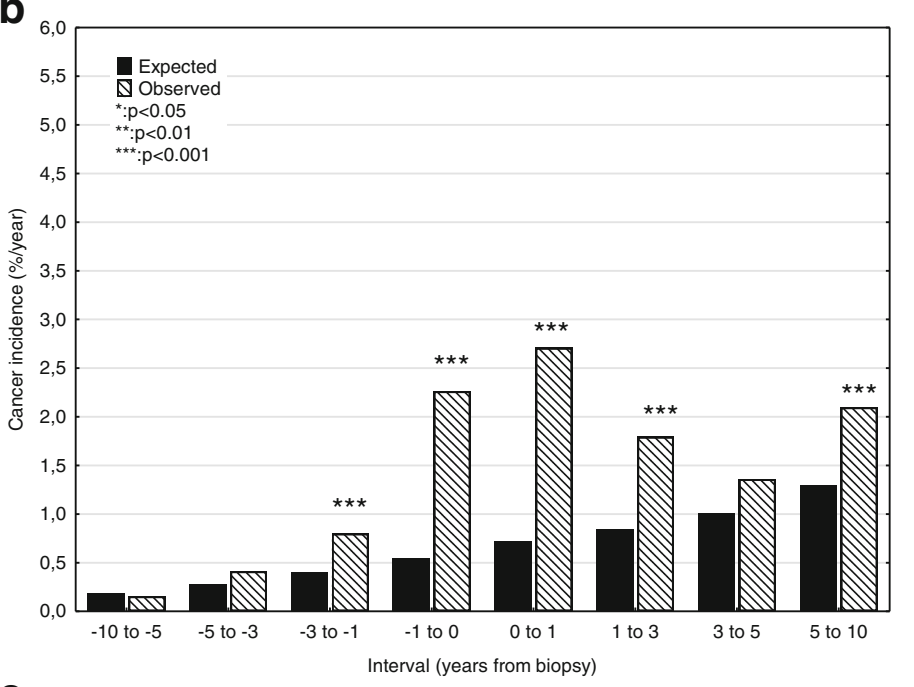

C

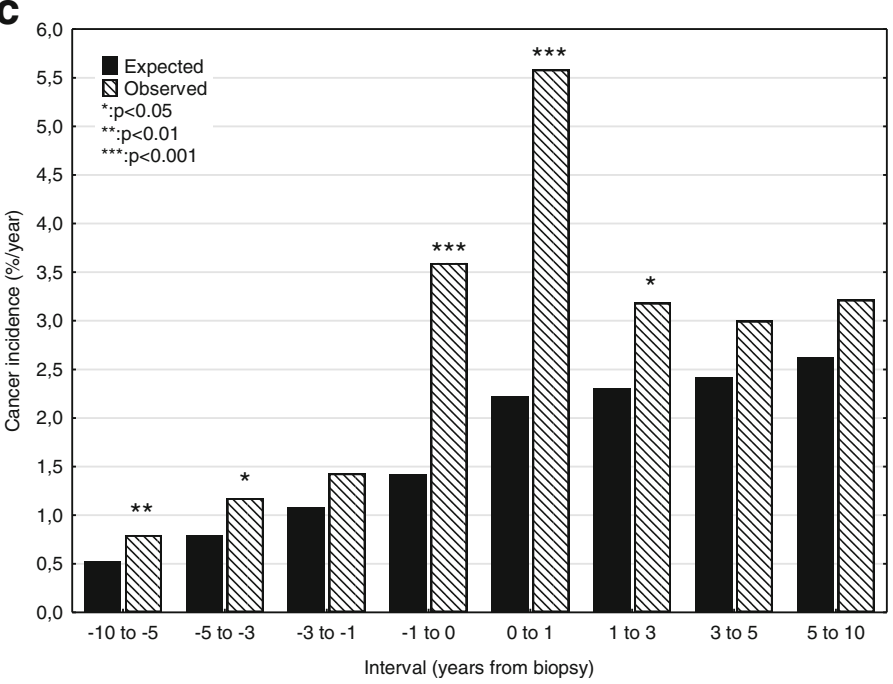

Fig. 2 Observed and expected any cancer incidences according to age group. a 15-44 years; b 45-64 years; c > 64 years 

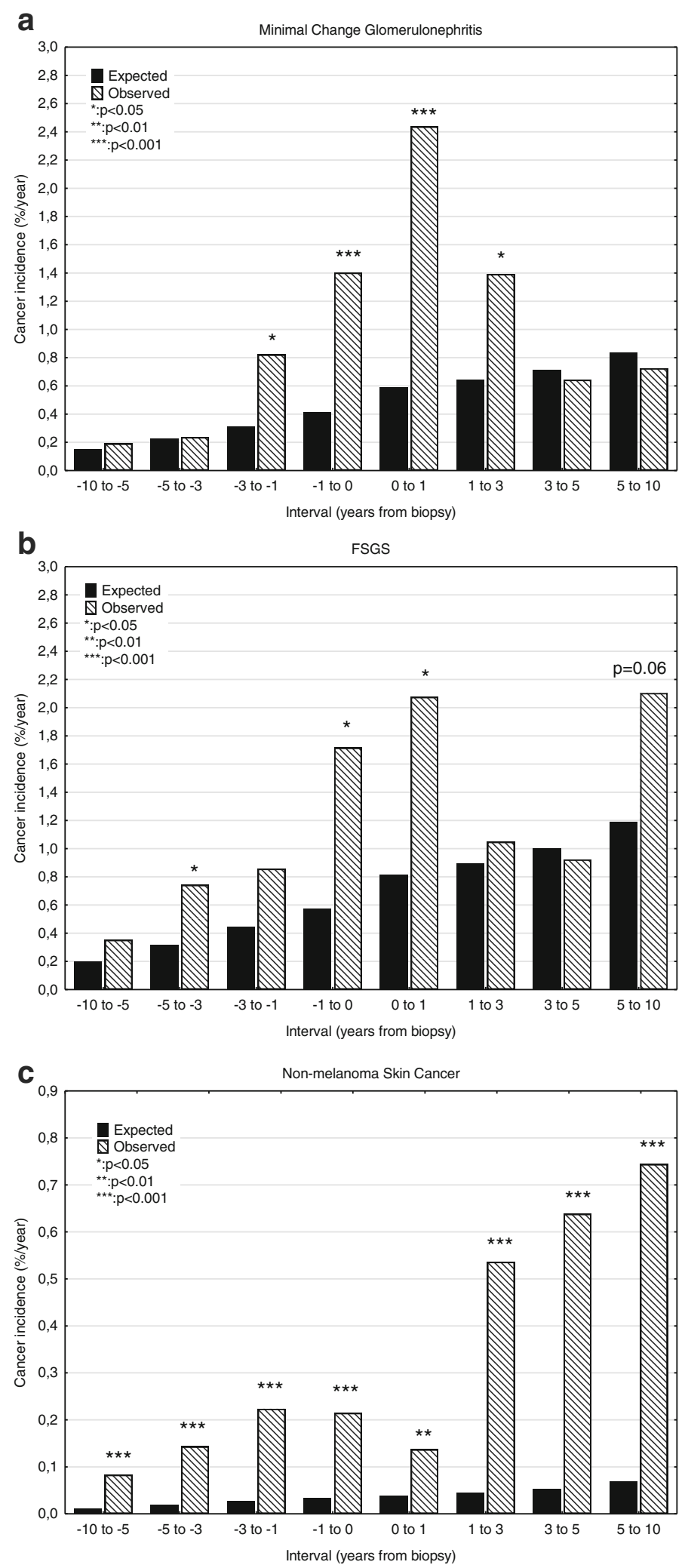

Fig. 3 (See legend on next page.) 
(See figure on previous page.)

Fig. 3 Patterns of observed cancer incidences according to time relationship to biopsy. a Usual pattern, with increase mainly limited to period -1 to 1 year after biopsy; $\mathbf{b}$ Increased incidence around biopsy date, with late increase (membranous nephropathy, FSGS, mesangioproliferative GN, proliferative, focal segmental proliferative GN; c increasing incidence during period of observation (focal segmental proliferative GN, nonmelanoma skin cancer)

caused by a third factor. It is probable that the relationship is partly coincidental: an investigation for cancer may by chance reveal an undiscovered GN and vice versa [19]. This possibility is particularly relevant for renal cancer and myeloma, where renal biopsy may be included in the routine diagnosis of these diseases. Implementation of cancer screening for GN, which is common for $\mathrm{MN}$ will have hastened the diagnosis of subclinical cancers. However, if a renal biopsy resulted in a major overall shortening of the time to cancer diagnosis, one would expect that incidence for that cancer form would fall to below expected for the period 1-3 years after biopsy. Finally, the increased rate may be due to the carcinogenic effects of GN treatment. However, the effect of therapy is unlikely to have played a role in the $36 \%$ of cancers that were present at biopsy.

Table 3 The association of cancer diagnosis to observed and expected cancer incidence (\%/year) grouped according to time interval relative to biopsy date

\begin{tabular}{|c|c|c|c|c|c|c|c|c|c|c|}
\hline Time interval (years) & & -10 to -5 & -5 to -3 & -3 to -1 & -1 to 0 & $0-1$ & $1-3$ & $3-5$ & $5-10$ & -10 to 10 \\
\hline \multirow[t]{3}{*}{ Colorectal } & Observed & 0.03 & 0.06 & 0.05 & 0.07 & 0.26 & 0.06 & 0.14 & 0.17 & 0.08 \\
\hline & Expected & 0.05 & 0.09 & 0.12 & 0.17 & 0.22 & 0.24 & 0.27 & 0.33 & 0.16 \\
\hline & Risk ratio & $\begin{array}{l}0.5 \\
(0,2-1.0)\end{array}$ & $\begin{array}{l}0.7 \\
(0.3-1.5)\end{array}$ & $\begin{array}{l}0.4 \\
(0.2-0.9)^{\mathrm{b}}\end{array}$ & $\begin{array}{l}0.4 \\
(0.1-1.1)\end{array}$ & $\begin{array}{l}1.2 \\
(0.6-2.1)\end{array}$ & $\begin{array}{l}0.2 \\
(0.1-0.5)^{d}\end{array}$ & $\begin{array}{l}0.5 \\
(0.2-1.0)\end{array}$ & $\begin{array}{l}0.5 \\
(0.3-0.9)^{c}\end{array}$ & $\begin{array}{l}0.5 \\
(0.4-0.6)^{d}\end{array}$ \\
\hline \multirow[t]{3}{*}{ Lung } & Observed & 0.00 & 0.03 & 0.04 & 0.20 & 0.32 & 0.26 & 0.17 & 0.23 & 0.10 \\
\hline & Expected & 0.01 & 0.01 & 0.02 & 0.06 & 0.12 & 0.13 & 0.14 & 0.16 & 0.06 \\
\hline & Risk ratio & $\begin{array}{l}0.7 \\
(0-3.9)\end{array}$ & $\begin{array}{l}2.8 \\
(0.6-8.2)\end{array}$ & $\begin{array}{l}1.8 \\
(0.5-4.6)\end{array}$ & $\begin{array}{l}3.1 \\
(1.6-5.6)^{c}\end{array}$ & $\begin{array}{l}2.7 \\
(1.5-4.4)^{d}\end{array}$ & $\begin{array}{l}2.0 \\
(1.2-3.1)^{c}\end{array}$ & $\begin{array}{l}1.2 \\
(0.6-2.3)\end{array}$ & $\begin{array}{l}1.4 \\
(0.9-2.1)\end{array}$ & $\begin{array}{l}1.6 \\
(1.3-2.0)^{d}\end{array}$ \\
\hline \multirow[t]{3}{*}{ Melanoma } & Observed & 0.01 & 0.03 & 0.01 & 0.04 & 0.02 & 0.07 & 0.07 & 0.08 & 0.03 \\
\hline & Expected & 0.02 & 0.02 & 0.03 & 0.03 & 0.03 & 0.03 & 0.03 & 0.04 & 0.03 \\
\hline & Risk ratio & $\begin{array}{l}0.7 \\
(0.2-2.1)\end{array}$ & $\begin{array}{l}1.3 \\
(0.3-3.7)\end{array}$ & $\begin{array}{l}0.3 \\
(0-1.8)\end{array}$ & $\begin{array}{l}1.1 \\
(0.1-3.9)\end{array}$ & $\begin{array}{l}0.6 \\
(0-3.4)\end{array}$ & $\begin{array}{l}2.3 \\
(0.8-5.0)\end{array}$ & $\begin{array}{l}2.1 \\
(0.6-5.5)\end{array}$ & $\begin{array}{l}2.1 \\
(0.9-4.4)\end{array}$ & $\begin{array}{l}1.2 \\
(0.8-1.7)\end{array}$ \\
\hline \multirow[t]{3}{*}{ Breast $^{\mathrm{a}}$} & Observed & 0.13 & 0.11 & 0.11 & 0.22 & 0.19 & 0.12 & 0.03 & 0.28 & 0.15 \\
\hline & Expected & 0.09 & 0.12 & 0.17 & 0.18 & 0.18 & 0.19 & 0.20 & 0.22 & 0.15 \\
\hline & Risk ratio & $\begin{array}{l}1.4 \\
(0.8-2.3)\end{array}$ & $\begin{array}{l}0.9 \\
(0.3-2.0)\end{array}$ & $\begin{array}{l}0.6 \\
(0.2-1.5)\end{array}$ & $\begin{array}{l}1.2 \\
(0.4-2.8)\end{array}$ & $\begin{array}{l}1.0 \\
(0.3-2.7)\end{array}$ & $\begin{array}{l}0.6 \\
(0.2-1.6)\end{array}$ & $\begin{array}{l}0.1 \\
(0-0.8)^{b}\end{array}$ & $\begin{array}{l}1.2 \\
(0.7-2.0)\end{array}$ & $\begin{array}{l}1.0 \\
(0.7-1.3)\end{array}$ \\
\hline \multirow[t]{3}{*}{ Gynaecologic $^{a}$} & Observed & 0.02 & 0.02 & 0.09 & 0.13 & 0.05 & 0.03 & 0.09 & 0.05 & 0.05 \\
\hline & Expected & 0.04 & 0.05 & 0.06 & 0.07 & 0.09 & 0.09 & 0.10 & 0.11 & 0.07 \\
\hline & Risk ratio & $\begin{array}{l}0.4 \\
(0.1-1.5)\end{array}$ & $\begin{array}{l}0.4 \\
(0-2.5)\end{array}$ & $\begin{array}{l}1.4 \\
(0.4-3.6)\end{array}$ & $\begin{array}{l}1.7 \\
(0.4-5.1)\end{array}$ & $\begin{array}{l}0.5 \\
(0-3.0)\end{array}$ & $\begin{array}{l}0.4 \\
(0-2.1)\end{array}$ & $\begin{array}{l}1.0 \\
(0.2-2.8)\end{array}$ & $\begin{array}{l}0.5 \\
(0.1-1.2)\end{array}$ & $\begin{array}{l}0.7 \\
(0.4-1.2)\end{array}$ \\
\hline \multirow[t]{3}{*}{ Prostate $^{a}$} & Observed & 0.04 & 0.08 & 0.12 & 0.49 & 0.74 & 0.22 & 0.20 & 0.27 & 0.19 \\
\hline & Expected & 0.04 & 0.09 & 0.15 & 0.17 & 0.18 & 0.20 & 0.22 & 0.27 & 0.14 \\
\hline & Risk ratio & $\begin{array}{l}1.1 \\
(0.5-2.3)\end{array}$ & $\begin{array}{l}0.8 \\
(0.3-1.9)\end{array}$ & $\begin{array}{l}0.8 \\
(0.4-1.6)\end{array}$ & $\begin{array}{l}2.9 \\
(1.7-4.8)^{d}\end{array}$ & $\begin{array}{l}4.2 \\
(2.6-6.5)^{d}\end{array}$ & $\begin{array}{l}1.1 \\
(0.5-2.0)\end{array}$ & $\begin{array}{l}0.9 \\
(0.4-1.9)\end{array}$ & $\begin{array}{l}1.0 \\
(0.6-1.6)\end{array}$ & $\begin{array}{l}1.3 \\
(1.1-1.7)^{d}\end{array}$ \\
\hline \multirow[t]{3}{*}{ Renal } & Observed & 0.01 & 0.02 & 0.03 & 0.29 & 0.16 & 0.03 & 0 & 0.05 & 0.05 \\
\hline & Expected & 0.004 & 0.01 & 0.01 & 0.01 & 0.02 & 0.02 & 0.02 & 0.02 & 0.01 \\
\hline & Risk ratio & $\begin{array}{l}2.0 \\
(0.2-7.1)\end{array}$ & $\begin{array}{l}2.9 \\
(0.3-10.4)\end{array}$ & $\begin{array}{l}3.0 \\
(0.6-8.6)\end{array}$ & $\begin{array}{l}21.4 \\
(12.2-34.8)^{d}\end{array}$ & $\begin{array}{l}9.2 \\
(4.0-18.2)^{d}\end{array}$ & $\begin{array}{l}1.8 \\
(0.4-5.1)\end{array}$ & $\begin{array}{l}0 \\
(0-2.4)\end{array}$ & $\begin{array}{l}2.3 \\
(0.9-4.7)^{b}\end{array}$ & $\begin{array}{l}4.1 \\
(2.9-3.5)^{d}\end{array}$ \\
\hline \multirow[t]{3}{*}{ Bladder } & Observed & 0.01 & 0.02 & 0.03 & 0 & 0.02 & 0.05 & 0.05 & 0.09 & 0.03 \\
\hline & Expected & 0.02 & 0.03 & 0.04 & 0.05 & 0.06 & 0.07 & 0.08 & 0.09 & 0.05 \\
\hline & Risk ratio & $\begin{array}{l}0.2 \\
(0-0.9)^{b}\end{array}$ & $\begin{array}{l}0.6 \\
(0.1-2.0)\end{array}$ & $\begin{array}{l}0.7 \\
(0.1-1.9)\end{array}$ & $\begin{array}{l}0 \\
(0-1.3)\end{array}$ & $\begin{array}{l}0.3 \\
(0-1.8)\end{array}$ & $\begin{array}{l}0.7 \\
(0.1-2.1)\end{array}$ & $\begin{array}{l}0.6 \\
(0.1-1.8)\end{array}$ & $\begin{array}{l}0.9 \\
(0.4-1.9)\end{array}$ & $\begin{array}{l}0.5 \\
(0.3-0.8)^{c}\end{array}$ \\
\hline \multirow[t]{3}{*}{ Hodgkin lymphoma } & Observed & 0 & 0.01 & 0.01 & 0 & 0.02 & 0 & 0.00 & 0.01 & 0.004 \\
\hline & Expected & 0.002 & 0.002 & 0.002 & 0.003 & 0.003 & 0.003 & 0.003 & 0.003 & 0.003 \\
\hline & Risk ratio & $\begin{array}{l}0 \\
(0-6.7)\end{array}$ & $\begin{array}{l}3.9 \\
(0.1-21.7)\end{array}$ & $\begin{array}{l}3.7 \\
(0.1-20.8)\end{array}$ & $\begin{array}{l}0 \\
(0-25.2)\end{array}$ & $\begin{array}{l}6.3 \\
(0.2-34.9)\end{array}$ & $\begin{array}{l}0 \\
(0-13.9)\end{array}$ & $\begin{array}{l}0 \\
(0-15.8)\end{array}$ & $\begin{array}{l}3.2 \\
(0.1-17.9)\end{array}$ & $\begin{array}{l}1.6 \\
(0.4-4.2)\end{array}$ \\
\hline
\end{tabular}


Table 3 The association of cancer diagnosis to observed and expected cancer incidence (\%/year) grouped according to time interval relative to biopsy date (Continued)

\begin{tabular}{|c|c|c|c|c|c|c|c|c|c|c|}
\hline Time interval (years) & & -10 to -5 & -5 to -3 & -3 to -1 & -1 to 0 & $0-1$ & $1-3$ & $3-5$ & $5-10$ & -10 to 10 \\
\hline \multirow{3}{*}{$\begin{array}{l}\text { Non-Hodgkin } \\
\text { Lymphoma }\end{array}$} & Observed & 0.01 & 0.02 & 0.03 & 0.16 & 0.17 & 0.03 & 0.06 & 0.06 & 0.04 \\
\hline & Expected & 0.01 & 0.01 & 0.01 & 0.02 & 0.02 & 0.02 & 0.03 & 0.03 & 0.02 \\
\hline & Risk ratio & $\begin{array}{l}1.4 \\
(0.3-4.2)\end{array}$ & $\begin{array}{l}1.5 \\
(0.2-5.5)\end{array}$ & $\begin{array}{l}1.8 \\
(0.4-5.3)\end{array}$ & $\begin{array}{l}8.1 \\
(3.7-15.4)^{d}\end{array}$ & $\begin{array}{l}7.3 \\
(3.1-14.3)^{d}\end{array}$ & $\begin{array}{l}1.1 \\
(0.1-4.0)\end{array}$ & $\begin{array}{l}2.3 \\
(0.6-5.9)\end{array}$ & $\begin{array}{l}1.9 \\
(0.7-4.1)\end{array}$ & $\begin{array}{l}2.5 \\
(1.8-3.5)^{d}\end{array}$ \\
\hline \multirow[t]{3}{*}{ Myeloma } & Observed & 0.004 & 0.01 & 0.02 & 0.23 & 0.44 & 0.02 & 0 & 0.02 & 0.05 \\
\hline & Expected & 0.001 & 0.003 & 0.01 & 0.01 & 0.01 & 0.01 & 0.01 & 0.01 & 0.01 \\
\hline & Risk ratio & $\begin{array}{l}3.1 \\
(0.1-17.4)\end{array}$ & $\begin{array}{l}3.0 \\
(0.1-16.8)\end{array}$ & $\begin{array}{l}3.6 \\
(0.4-12.9)\end{array}$ & $\begin{array}{l}32.6 \\
(17.3-55.7)^{d}\end{array}$ & $\begin{array}{l}49.4 \\
(31.0-74.8)^{d}\end{array}$ & $\begin{array}{l}2.2 \\
(0.3-7.8)\end{array}$ & $\begin{array}{l}0 \\
(0-4.4)\end{array}$ & $\begin{array}{l}1.6 \\
(0.3-4.8)\end{array}$ & $\begin{array}{l}8.6 \\
(6.3-11.6)^{d}\end{array}$ \\
\hline \multirow[t]{3}{*}{ Leukaemia } & Observed & 0.01 & 0.03 & 0.06 & 0.09 & 0.17 & 0.03 & 0.05 & 0.06 & 0.04 \\
\hline & Expected & 0.01 & 0.02 & 0.02 & 0.03 & 0.04 & 0.05 & 0.05 & 0.06 & 0.03 \\
\hline & Risk ratio & $\begin{array}{l}0.8 \\
(0.1-2.8)\end{array}$ & $\begin{array}{l}1.7 \\
(0.4-5.0)\end{array}$ & $\begin{array}{l}2.9 \\
(1.2-6.0)^{b}\end{array}$ & $\begin{array}{l}3.1 \\
(1.0-7.3)^{b}\end{array}$ & $\begin{array}{l}3.9 \\
(1.7-7.7)^{c}\end{array}$ & $\begin{array}{l}0.7 \\
(0.1-2.5)\end{array}$ & $\begin{array}{l}1.0 \\
(0.2-2.8)\end{array}$ & $\begin{array}{l}0.9 \\
(0.4-1.9)\end{array}$ & $\begin{array}{l}1.5 \\
(1.0-2.0)^{b}\end{array}$ \\
\hline \multirow{3}{*}{$\begin{array}{l}\text { Skin } \\
\text { (non-melanoma) }\end{array}$} & Observed & 0.08 & 0.14 & 0.22 & 0.21 & 0.14 & 0.54 & 0.64 & 0.74 & 0.27 \\
\hline & Expected & 0.01 & 0.02 & 0.03 & 0.03 & 0.04 & 0.04 & 0.05 & 0.07 & 0.03 \\
\hline & Risk ratio & $\begin{array}{l}7.8 \\
(4.9-11.7)^{c}\end{array}$ & $\begin{array}{l}7.4 \\
(4.2-12.0)^{d}\end{array}$ & $\begin{array}{l}8.6 \\
(5.5-12.6)^{d}\end{array}$ & $\begin{array}{l}6.4 \\
(3.3-11.1)^{d}\end{array}$ & $\begin{array}{l}3.6 \\
(1.5-7.5)^{c}\end{array}$ & $\begin{array}{l}12.1 \\
(8.7-16.3)^{d}\end{array}$ & $\begin{array}{l}12.1 \\
(8.5-16.7)^{d}\end{array}$ & $\begin{array}{l}10.9 \\
(8.5-13.8)^{d}\end{array}$ & $\begin{array}{l}8.7 \\
(7.6-9.9)^{d}\end{array}$ \\
\hline \multirow[t]{3}{*}{ Unclassified } & Observed & 0.04 & 0.05 & 0.07 & 0.22 & 0.53 & 0.33 & 0.25 & 0.43 & 0.17 \\
\hline & Expected & 0.04 & 0.05 & 0.07 & 0.11 & 0.19 & 0.20 & 0.22 & 0.25 & 0.12 \\
\hline & Risk ratio & $\begin{array}{l}1.1 \\
(0.6-2.0)\end{array}$ & $\begin{array}{l}1.1 \\
(0.4-2.4)\end{array}$ & $\begin{array}{l}1.0 \\
(0.4-2.0)\end{array}$ & $\begin{array}{l}1.9 \\
(1.0-3.3)^{\mathrm{b}}\end{array}$ & $\begin{array}{l}2.8 \\
(1.9-4.1)^{d}\end{array}$ & $\begin{array}{l}1.6 \\
(1.1-2.4)^{b}\end{array}$ & $\begin{array}{l}1.1 \\
(0.7-1.8)\end{array}$ & $\begin{array}{l}1.7 \\
(1.2-2.3)^{c}\end{array}$ & $\begin{array}{l}1.5 \\
(1.2-1.7)^{d}\end{array}$ \\
\hline \multirow[t]{3}{*}{ Any not skin } & Observed & 0.20 & 0.35 & 0.46 & 1.63 & 2.37 & 0.99 & 0.77 & 1.06 & 0.71 \\
\hline & Expected & 0.19 & 0.30 & 0.41 & 0.55 & 0.80 & 0.86 & 0.95 & 1.10 & 0.55 \\
\hline & Risk ratio & $\begin{array}{l}1.0 \\
(0.8-1.3)\end{array}$ & $\begin{array}{l}1.2 \\
(0.8-1.6)\end{array}$ & $\begin{array}{l}1.1 \\
(0.8-1.5)\end{array}$ & $\begin{array}{l}2.9 \\
(2.6-3.4)^{d}\end{array}$ & $\begin{array}{l}3.0 \\
(2.5-3.6)^{d}\end{array}$ & $\begin{array}{l}1.1 \\
(0.9-1.4)\end{array}$ & $\begin{array}{l}0.8 \\
(0.6-1.1)\end{array}$ & $\begin{array}{l}1.0 \\
(0.8-1.1)\end{array}$ & $\begin{array}{l}1.3 \\
(1.2-1.4)^{d}\end{array}$ \\
\hline
\end{tabular}

Significant risk ratios in bold type

${ }^{a}$ : relevant sex only. ${ }^{b}:<0.05 ;{ }^{c}:<0.01 ;{ }^{d}:<0.001$

Only five diseases, MesPGN, proliferative, FSGS, FSPGN and $\mathrm{MN}$ showed a late rise in incidence. While FSGS treatment is rarely carcinogenic, carcinogenic therapy, e.g. azathioprine and cyclophosphamide is common in MesPGN, MPGN, anti-GBMGN, lupus GN and ANCAV. These observations do not exclude the possibility that initiation of immunosuppressive therapy might cause the rapid progression of an already present sub-clinical cancer to clinical disease during the first year of treatment. The lack of a major association between cancer and non-nephrotic proteinuria or haematuria suggests that cancer is mainly associated with severe renal disease. Similarly, if one assumes that disease diagnosis time point is associated with disease severity and/or accelerating activity, the close temporal conjunction of the cancer and GN diagnoses suggest that any aetiological common agent is proportional to disease severity. One can speculate that the late rise in cancer incidence for patients with proteinuria and haematuria is thus

Table 4 Individual cases of other cancers described in the literature as related to $G N[3,4]$

\begin{tabular}{|c|c|c|c|c|c|c|}
\hline Renal Diagnosis & Stomach & Pancreas & Liver & Sarcoma & Brain & Thymus \\
\hline Minimal Change & $0^{a}$ & $0^{a}$ & 1 & $0^{\mathrm{a}}$ & & $0^{a}$ \\
\hline FSGS & $2^{a}$ & $2^{a}$ & & $1^{\mathrm{a}}$ & $0^{a}$ & $0^{a}$ \\
\hline Mesangioproliferative & 4 & 2 & 2 & & & $0^{a}$ \\
\hline Membranous & $1^{\mathrm{a}}$ & $2^{\mathrm{a}}$ & $1^{\mathrm{a}}$ & $1^{\mathrm{a}}$ & $1^{a}$ & \\
\hline Membranoproliferative & $0^{a}$ & $1^{\mathrm{a}}$ & 1 & & & \\
\hline Focal segmental proliferative & & 3 & & & 1 & \\
\hline Crescentic & $1^{a}$ & & $1^{a}$ & & & $0^{a}$ \\
\hline Unclassified & 4 & & 2 & & & \\
\hline ANCA vasculitis & 2 & & & & & \\
\hline
\end{tabular}

${ }^{a}$ associations described in the literature 


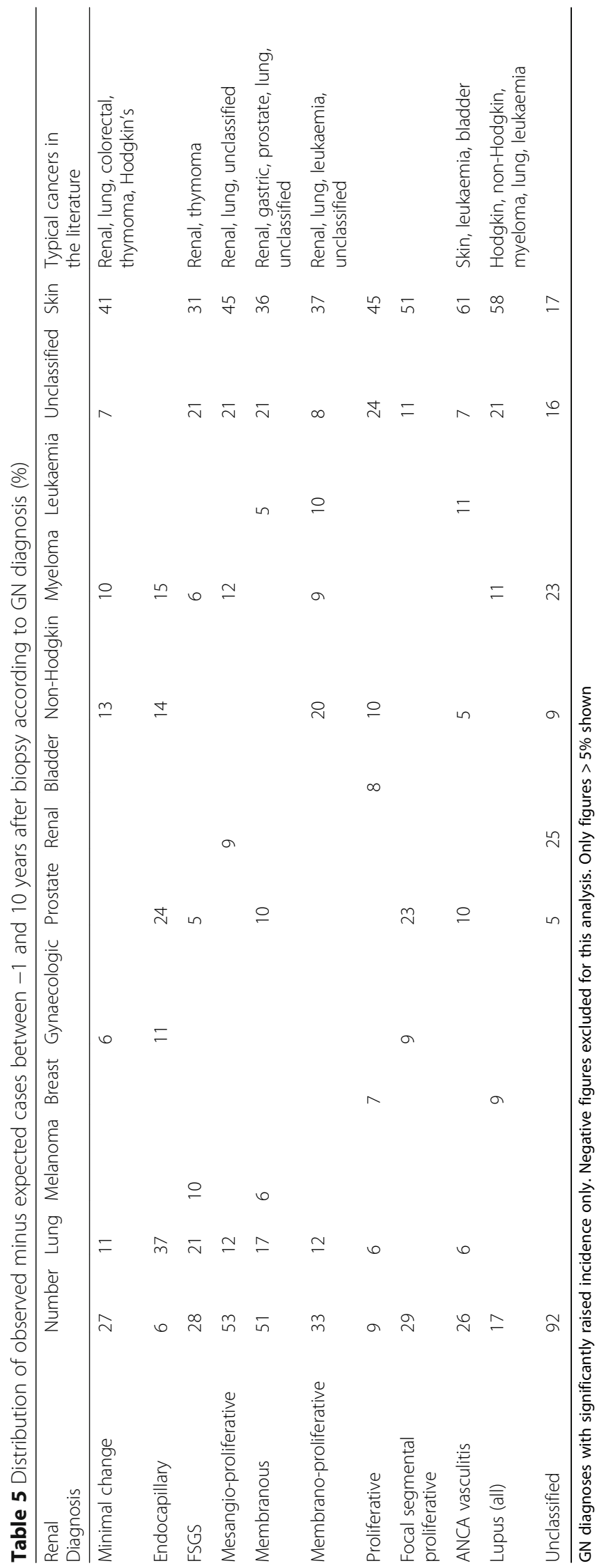




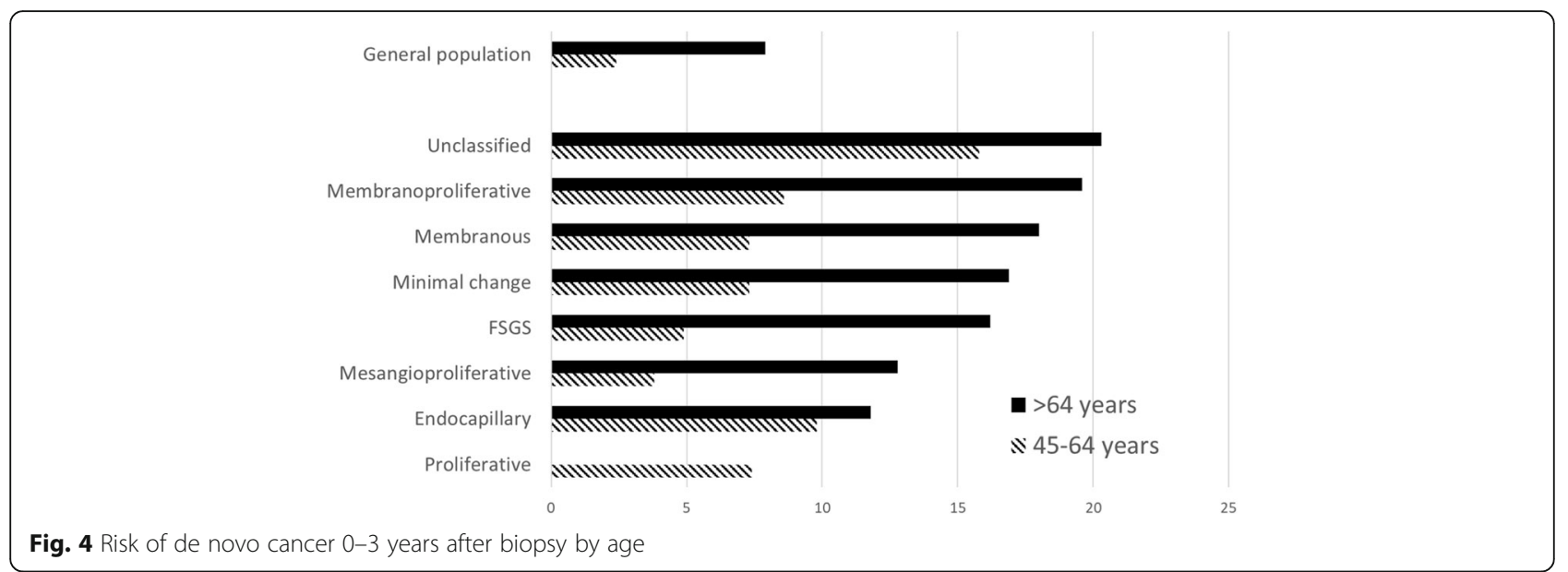

caused by progression of the renal disease to more severe forms.

The association of specific cancers to specific GN diagnoses are shown in Tables 5 and 6 . These are at some variance with the literature. There are well-known associations between both Hodgkin lymphoma [20] and thymoma [18] and MCD; this paper cannot contribute to this discussion due to too few patients. Other well recognized associations are solid tumours and MN [3], chronic lymphocytic leukemia and MPGN [21], and renal cell carcinomas and IgA nephropathy [22]. Possible aetiological mechanisms for these relationships include tumour-antibody production against shed tumour antigens (solid tumours and MN) [19]; putative circulating factor secreted by $\mathrm{T}$ lymphocytes, inducing glomerular cell cytoskeleton degeneration (Hodgkin lymphoma and MCD) [23]; B-cell production of either a cryoglobulin or M-component (chronic lymphocytic leukemia and MPGN) [24]. We found more non-specific relations between tumour type and GN diagnosis. This is not entirely unexpected: Lien et al. also found substantial variation in the linkage between GN form and cancer type [5]. There are several possible explanations for the discrepancies. The most common form of cancer was non-melanoma skin cancer. Since most of these cancers are cured at diagnosis, previous studies may have missed these cases. The actual numbers of cancers in each published series will be small, so considerable variation in relative incidence must be expected. Even in the present large study, the number of non-skin cancers per GN diagnosis only varied between 6 and 33. In contrast to other studies, where all cases of cancer were described, Tables 5 and 6 only study the relationship to excess tumours over and above the expected; this will tend to reduce the contribution of common cancers. We suggest therefore that our figures are more accurate than other studies; however, this question can only be resolved by a metaanalysis. It may even be possible that

Table 6 Distribution of 378 observed minus expected cases between -1 and 10 years after biopsy according to cancer diagnosis (\%)

\begin{tabular}{|c|c|c|c|c|c|c|c|c|c|c|c|c|c|}
\hline Cancer Diagnosis & Number & MCD & End & FSGS & MesPGN & MN & MPGN & FSPGN & Focal & NCGN & Unclassified & ANCAV & Typical GN in the literature [4] \\
\hline Lung & 37 & 8 & 6 & 16 & 17 & 23 & 11 & & & 6 & & & $\begin{array}{l}\text { MN, MCD, MPGN, } \\
\text { MesPGN, FSGS, NCGN }\end{array}$ \\
\hline Prostate & 33 & & & & & 16 & & 20 & & 28 & 15 & 8 & MCD, NCGN \\
\hline Renal & 30 & & & & 16 & & & & & & 78 & & $\begin{array}{l}\text { NCGN, MesPGN, } \\
\text { MCD, FSGS, MPGN }\end{array}$ \\
\hline Non-Hodgkin & 22 & 15 & & & & & 30 & & & & 36 & 6 & $\begin{array}{l}\text { MN, MCD, MPGN, } \\
\text { FSGS, NCGN }\end{array}$ \\
\hline Myeloma & 37 & 7 & & 5 & 17 & & 8 & & & & 55 & & \\
\hline Leukemia & 15 & & & & & 16 & 23 & 10 & 10 & & 22 & 19 & $\begin{array}{l}\text { MN, MCD, } \\
\text { MPGN, FSGS, NCGN }\end{array}$ \\
\hline $\begin{array}{l}\text { Skin } \\
\text { (non-melanoma) }\end{array}$ & 152 & 7 & & 6 & 16 & 12 & 8 & 10 & & 12 & 11 & 10 & MN \\
\hline Unclassified & 56 & & & 11 & 20 & 19 & 5 & & 6 & & 26 & & \\
\hline
\end{tabular}

Cancer diagnoses with significantly raised incidence only. Negative figures excluded for this analysis. Only figures $>5 \%$ shown. MCD: minimal change disease $M N$ membranous nephropathy, FSGS focal segmental glomerulosclerosis, MesPGN mesangioproliferative GN, MPGN Membranoproliferative GN, FSPGN focal segmental proliferative GN, NCGN necrotizing and crescentic GN 


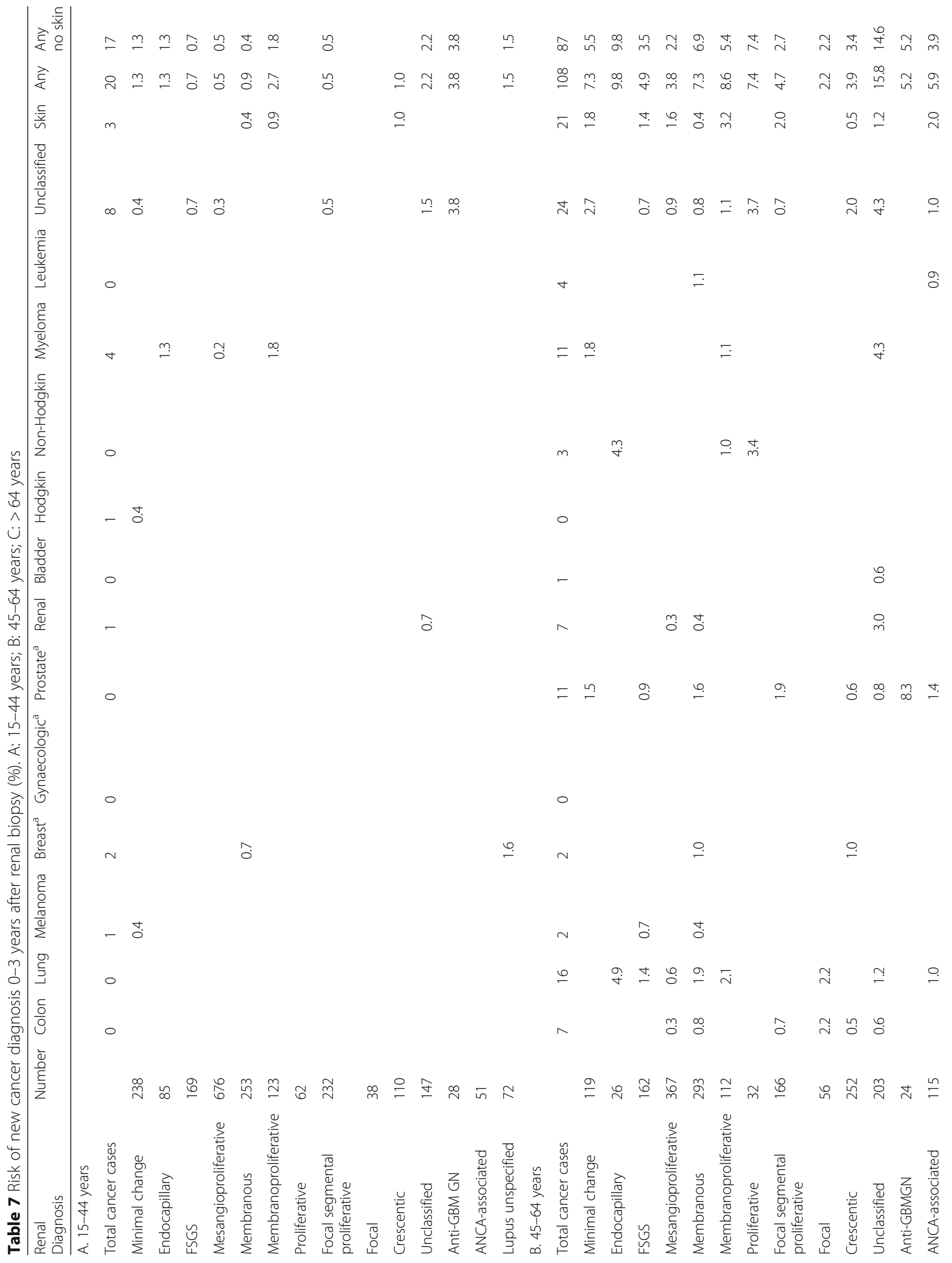


Heaf et al. BMC Nephrology (2018) 19:27

Page 14 of 16

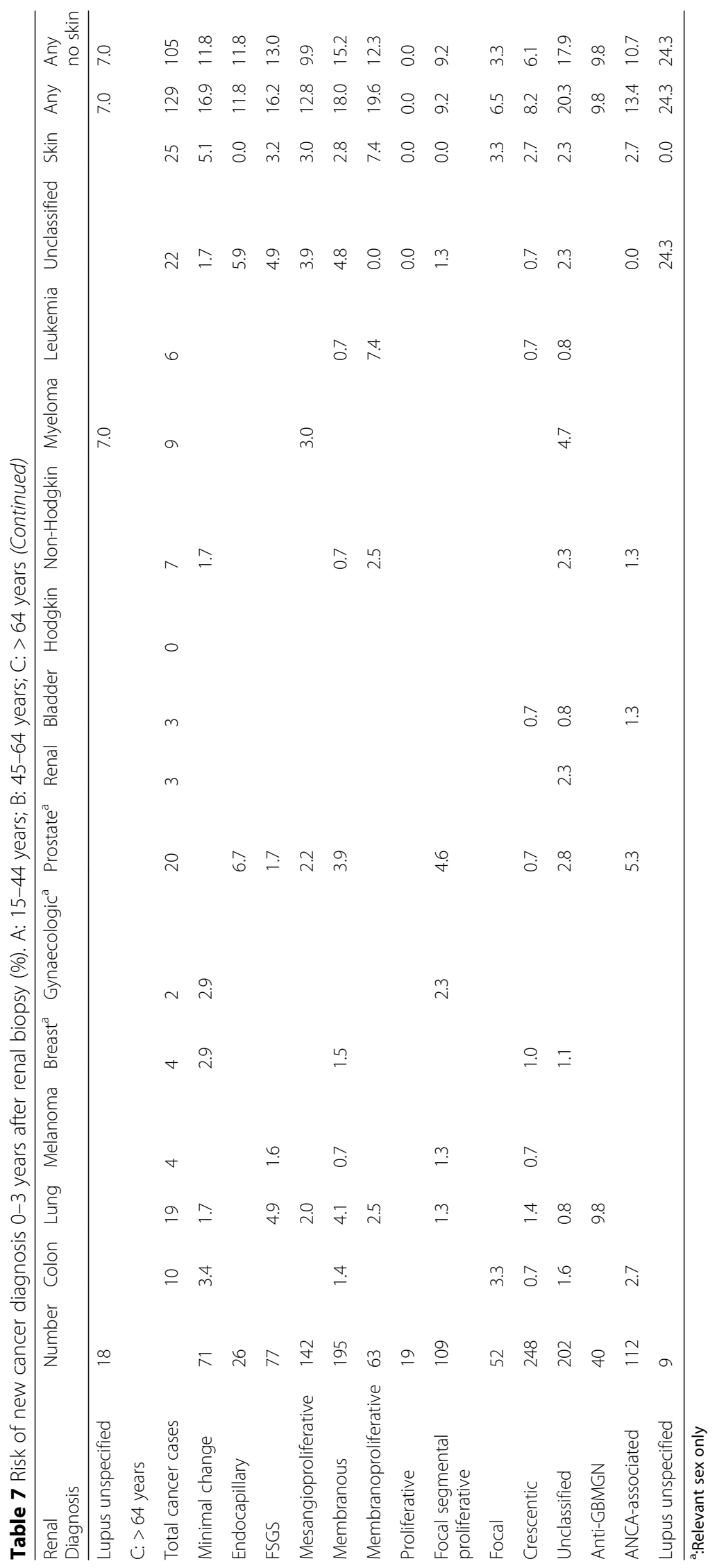


GN has a non-specific carcinogenic effect (or vice versa), and that previous associations with specific diagnoses rest upon an overinterpretation of small series. The practical consequence of these findings is that the presence of most GN forms should result in a generally increased non-specific suspicion of cancer.

The distribution of cancers being diagnosed 0-3 years after renal diagnosis are shown in Table 7 and Fig. 4 . Assuming that most of these cancers can be diagnosed at biopsy, this table has practical significance. Cancer screening for $\mathrm{MN}$ has received considerable attention. Some authors $[6,25]$ recommend extensive screening including gastroscopy, colonoscopy, gynaecological investigation, ultrasonic renal scanning and CT thorax, while others do not advise other than standard age-specific screening in the absence of specific symptoms or objective findings. The KDIGO guidelines recommend specific malignancy screening for MN, FSGS and IgA GN, but not other forms of GN. The present study suggests that a more general suspicion of cancer should exist for other forms of GN. Patients under 45 years, and patients without uraemia or nephrotic syndrome do not appear to need further investigations. Otherwise measurement of myeloma protein, prostate specific antigen and a peripheral blood examination should be standard. An ultrasonic renal scan will usually be routine in connection with a renal biopsy. A CT thorax should be performed for smokers. Patients should be informed of an increased skin cancer risk and advised to reduce exposure to sun. Regular dermatological assessments may be beneficial. The present study does not suggest that there are indications for gastroscopy, coloscopy, gynaecological investigation or mammography, other than normal age-specific indications. Whole-body PET-CT or MR scans can be used for non-Hodgkin lymphoma and other rare malignancies, primarily for the GN diagnoses MPGN, MCD and unclassified GN. Figure 4 shows the risk of de novo cancer diagnoses after renal diagnosis, and can be used as a guideline for investigational programs.

A number of criticisms to this study can be raised. The study is limited to a small country, and the results may not be applicable to other populations. As this was a registry-based study, important clinical information was unavailable, such as the presence of HIV, hepatitis C and concurrent immunosuppressive therapy, which all lower immune tolerance. Biopsies were evaluated at different centres by different pathologists; some intraand inter-individual differences in diagnoses will have been unavoidable. IgA nephropathy was not studied specifically; most of these patients will have been classified as MesPGN. MPGN is a mixed morphological category which could contain C3GN, cryoglobulinaemic GN, and IgA nephropathy. Similarly, LN has a number of light microscopy patterns. We have attempted to avoid this issue for LN by providing analyses both for all
LN and for morphological subgroups. No data concerning potentially carcinogenic therapy were available. These problems document some of the limitations of registry-based research.

All cancers were assumed to be prevalent at first diagnosis, due to the difficulty of differentiating repeat registrations of the same cancer, cancer recurrence and de novo disease. Thus, the incidence rates presented here will be an underestimate of the true incidence, particularly for skin tumours (vide supra). While the study presents probably the largest number of patients and cancers addressing this question, sub-group analyses still often contain small numbers of cases, with large confidence intervals, and possibility of type 2 statistical errors. Similarly, the low incidence of rare tumours prevents meaningful conclusions for these. However, for more common forms of cancer, and cancer incidence generally, the study presents useful information for guiding physicians in screening practice.

\section{Conclusions}

Cancer rates are increased for many cancer and most GN diagnoses. This study presents the first systematic quantification of this risk. The increased incidence is mainly confined to 1 year prior to 1 year after the renal diagnosis. Some GN diagnoses demonstrate a rise in cancer 5 years after diagnosis, which may be related to possible carcinogenic therapy. Most GN forms should result in a generally increased non-specific suspicion of cancer. Cancer screening for patients $<45$ years and for patients without nephrosis or uraemia may not be necessary. This study presents useful information for guiding physicians in screening practice for common forms of cancer.

\section{Abbreviations \\ ANCAV: ANCA-associated vasculitis; Anti-GBMGN: Anti-glomerular basal membrane antibody glomerulonephritis; EndGN: Endocapillary \\ glomerulonephritis; FSGS: Focal segmental glomerulosclerosis; FSPGN: Focal segmental proliferative glomerulonephritis; GN: Glomerulonephritis; \\ LN: Lupus nephritis; MCD: Minimal change disease; \\ MesPGN: Mesangioproliferative glomerulonephritis; MN: Membranous nephropathy; MPGN: Membranoproliferative glomerulonephritis; NCGN: Necrotizing and crescentic glomerulonephritis; ProlGN: Proliferative glomerulonephritis}

\section{Acknowledgements \\ None.}

\section{Funding}

None.

Availability of data and materials

An anonymized data file is available from the corresponding author on request. The data used in this project are available on Open Science Framework, reference osf.io/425 $\times 9$. 


\section{Authors' contributions}

JGH: Protocol, data collection, manuscript preparation. AH: Design and approval of the pathology classification. GHL: Statistics. All authors read and approved the final manuscript.

\section{Ethics approval and consent to participate}

The project was approved by the Danish Data Protection Agency (REG-1322015), and by the Danish Patient Safety Authority (3-3013-1440/1). Due to the anonymized, non-invasive, retrospective nature of the study, the requirement for specific scientific ethical committee was waived by the Danish Patient Safety Authority.

\section{Consent for publication}

Due to the anonymized, non-invasive, retrospective nature of the study, the Danish Patient Safety Authority (3-3013-1440/1) has waved the requirement for individual patient approval.

\section{Competing interests}

The authors have no conflict of interest. The results presented in this paper have not been published previously in whole or part, except in abstract format.

\section{Publisher's Note}

Springer Nature remains neutral with regard to jurisdictional claims in published maps and institutional affiliations.

\section{Author details}

${ }^{1}$ Department of Medicine, Zealand University Hospital, Roskilde, Denmark. ${ }^{2}$ Institute of Clinical Medicine, Herlev Hospital, University of Copenhagen, Copenhagen, Denmark. ${ }^{3}$ Department of Production, Research and Innovation, Region Zealand, Sorø, Denmark.

\section{Received: 4 August 2017 Accepted: 22 January 2018}

Published online: 02 February 2018

\section{References}

1. Lee JC, Yamauchi H, Hopper J Jr. The association of cancer and the nephrotic syndrome. Ann Intern Med. 1966;64:41-51.

2. Cambier JF, Ronco P. Onco-nephrology: glomerular diseases with cancer. Clin J Am Soc Nephrol. 2012;7:1701-12.

3. Bacchetta J, Juillard L, Cochat P, Droz JP. Paraneoplastic glomerular diseases and malignancies. Crit Rev Oncol Hematol. 2009;70:39-58.

4. Jhaveri $\mathrm{KD}$, Shah $\mathrm{HH}$, Calderon $\mathrm{K}$, Campenot ES, Radhakrishnan J. Glomerular diseases seen with cancer and chemotherapy: a narrative review. Kidney Int. 2013;84:34-44

5. Lien YH, Lai LW. Pathogenesis, diagnosis and management of paraneoplastic glomerulonephritis. Nat Rev Nephrol. 2011;7:85-95.

6. Pani A, Porta C, Cosmai L, Melis P, Floris M, Piras D, et al. Glomerular diseases and cancer: evaluation of underlying malignancy. J Nephrol. 2016; 29:143-52.

7. Leeaphorn N, Kue AP, Thamcharoen N, Ungprasert P, Stokes MB, Knight EL. Prevalence of cancer in membranous nephropathy: a systematic review and meta-analysis of observational studies. Am J Nephrol. 2014;40:29-35.

8. Sawyer N, Wadsworth J, Wijnen M, Gabriel R. Prevalence, concentration, and prognostic importance of proteinuria in patients with malignancies. Br Med J (Clin Res Ed). 1988;296:1295-8.

9. Jorgensen L, Heuch I, Jenssen T, Jacobsen BK. Association of albuminuria and cancer incidence. J Am Soc Nephrol. 2008;19:992-8.

10. Puolijoki H, Mustonen J, Pettersson E, Pasternack A, Lahdensuo A. Proteinuria and haematuria are frequently present in patients with lung cancer. Nephrol Dial Transplant. 1989:4:947-50.

11. Bjorneklett R, Vikse BE, Svarstad E, Aasarod K, Bostad L, Langmark F, et al. Long-term risk of cancer in membranous nephropathy patients. Am J Kidney Dis. 2007;50:396-403.

12. Birkeland SA, Storm HH. Glomerulonephritis and malignancy: a populationbased analysis. Kidney Int. 2003;63:716-21.

13. von EE ADG, Egger M, Pocock SJ, Gotzsche PC, Vandenbroucke JP. The strengthening the reporting of observational studies in epidemiology (STROBE) statement: guidelines for reporting observational studies. Lancet. 2007:370:1453-7.

14. Heaf J. The Danish renal biopsy register. Kidney Int. 2004;66:895-7.
15. Marcussen N, Olsen S, Larsen S, Starklint H, Thomsen OF. Reproducibility of the WHO classification of glomerulonephritis. Clin Nephrol. 1995;44:220-4.

16. Engholm G, Ferlay J, Christensen N, Bray F, Gjerstorff ML, Klint A, et al. NORDCAN-a Nordic tool for cancer information, planning, quality control and research. Acta Oncol. 2010;49:725-36.

17. Audard V, Larousserie F, Grimbert P, Abtahi M, Sotto JJ, Delmer A, et al. Minimal change nephrotic syndrome and classical Hodgkin's lymphoma: report of 21 cases and review of the literature. Kidney Int. 2006;69:2251-60.

18. Karras A, de Montpreville V, Fakhouri F, Grunfeld JP, Lesavre P. Renal and thymic pathology in thymoma-associated nephropathy: report of 21 cases and review of the literature. Nephrol Dial Transplant. 2005:20:1075-82.

19. Beck LH Jr. Membranous nephropathy and malignancy. Semin Nephrol. 2010;30:635-44.

20. Mallouk A, Pham PT, Pham PC. Concurrent FSGS and Hodgkin's lymphoma: case report and literature review on the link between nephrotic glomerulopathies and hematological malignancies. Clin Exp Nephrol. 2006;10:284-9.

21. Da'as N, Polliack A, Cohen Y, Amir G, Darmon D, Kleinman Y, et al. Kidney involvement and renal manifestations in non-Hodgkin's lymphoma and lymphocytic leukemia: a retrospective study in 700 patients. Eur J Haematol. 2001;67:158-64

22. Magyarlaki T, Kiss B, Buzogany I, Fazekas A, Sukosd F, Nagy J. Renal cell carcinoma and paraneoplastic IgA nephropathy. Nephron. 1999:82:127-30.

23. Kuppers R, Schwering I, Brauninger A, Rajewsky K, Hansmann ML. Biology of Hodgkin's lymphoma. Ann Oncol. 2002;13(Suppl 1):11-8

24. Brouet JC, Clauvel JP, Danon F, Klein M, Seligmann M. Biologic and clinical significance of cryoglobulins. A report of 86 cases. Am J Med. 1974;57:775-88.

25. Zeng CH, Chen HM, Wang RS, Chen Y, Zhang SH, Liu L, et al. Etiology and clinical characteristics of membranous nephropathy in Chinese patients. Am J Kidney Dis. 2008;52:691-8.

\section{Submit your next manuscript to BioMed Central and we will help you at every step:}

- We accept pre-submission inquiries

- Our selector tool helps you to find the most relevant journal

- We provide round the clock customer support

- Convenient online submission

- Thorough peer review

- Inclusion in PubMed and all major indexing services

- Maximum visibility for your research

Submit your manuscript at www.biomedcentral.com/submit
Biomed Central 